\title{
MEDIATING EFFECT OF BRAND IMAGE AND BRAND TRUST BETWEEN E-WOM ON SMARTPHONE PURCHASE INTEREST IN TANGERANG CITY
}

\author{
Dewi Faye Maya*, Sulivyo Lod \\ Sekolah Tinggi Ilmu Ekonomi PPI, Indonesia \\ Bastaman Aam \\ University of Trilogi, Indonesia \\ `E-mail: fayemayadewi@stieppi.ac.id
}

\begin{abstract}
The population in this study is the people in Tangerang City who are at least 17 years old and know about smartphone products. The sample was taken by 150 respondents using purposive sampling. The data were obtained through questionnaires on the Likert scale 1-5, which has been widely used as an interval scale. The data was analyzed using Partial Least Square with the Smart PLS-3 software application program. From the results of this study can be concluded that: First, there is a positive and significant influence between eWOM on Brand Image with a value of $30,399>1.96$ Second, there is a positive and significant influence between eWOM on Buy Interest with a value of 2,788 $>1.96$. Third, there is a positive and significant influence between eWOM on Brand Trust with a value of 10,238 > 1.96. Fourth, there is a positive and significant influence between Brand Image on Buy Interest with a value of $4,896>1.96$. Fifth, there is a positive and significant influence between Brand Trust on Buy Interest with a value of 2,774 >1.96. Sixth, there is a positive and significant influence between eWOM on Buy Interest through Brand Image with a Sobel test statistic of $4,718>1.96$. Seventh, there is a positive and significant influence between eWOM on Buy Interest through Brand Trust with a Sobel test statistic of 2,247 > 1.96.
\end{abstract}

\section{KEY WORDS}

eWOM, brand image, brand trust, buy interest.

Smartphones are an expensive type of product, so purchasing them involves financial risks. For expensive products, consumer involvement will be high and brands can be used as indicators of product quality to reduce purchase risk (Monroe \& Suri 2003). Several studies have shown that branding and electronic word of mouth are extrinsic cues to consumers (Hawkins and Mothersbaugh, 2010).

Advances in internet technology mean word of mouth is not limited to face-to-face communication, but already in the form of electronic word of mouth. Numerous studies show that branding and electronic word of mouth influence the perception of risk and the perception of the quality of a product, further influencing purchase interest (Hawkins \& Mothersbaugh, 2010). EWOM is becoming a very important "place" or place for consumers to voice their opinion and is seen as more effective than offline WOM, due to its accessibility and wider reach (Jalilvand 2012). This new form of word of mouth has become an important factor in shaping consumer behaviour. The existence of recommendations or opinions from other consumers, for example in a review sharing platform or community, can influence consumers' buying interest (Jalilvand, 2012). Marketers explain that $61 \%$ of consumers are influenced by reviews, blogs and similar review sharing platforms. A CNNIC report explains that $53.9 \%$ of consumers will research the opinion or reviews of the product to purchase, $78.9 \%$ will see product reviews, and $90 \%$ of consumers will give product reviews. Infogroup Inc. found that $80 \%$ of consumers considering purchasing products online will research product reviews before making a purchase decision.

A company's brand image can affect long-term profits, encourage consumers' desire to buy products at premium prices, increase stock prices, competitive advantage, and 
marketing success (Yoo and Donthu, 2001), WOM can have a very strong influence on consumer perceptions of a product (Jalilvand, 2012). Brand trust is the willingness of consumers to trust the brand with all the risks because the promised brand expectations will give positive results (Lau and Lee, 1999). The business competition that prioritizes brand image variables, electronic word of mouth and brand trust occurs in smartphone products today. In Indonesia, well-known smartphones such as Samsung, iPhone, Oppo, Xiaomi, Vivo, Redmi, Poco, Blackberry, Nokia and Sonny Ericsson products, so that smartphones have a large segment and are aimed at the upper-middle class. Smartphone marketers need to know the impact of brand image, brand trust, word of mouth and consumer buying interest.

\section{LITERATURE REVIEW AND HYPOTHESIS DEVELOPMENT}

Brand image can be interpreted as a set of beliefs that consumers have about a particular brand (Kotler 2002). That is, the brand image consists of the many beliefs held by consumers regarding the brand. Customers can develop various brand beliefs about the position of each brand based on their respective attributes. Brand trust forms a brand image or brand image. Every customer has a certain impression of a brand, which can arise after seeing, hearing, reading or hearing the product brand, through TV, radio or print media (Kotler, 2002). Brand image is the customer's perception of a brand which is represented through brand associations in the customer's memory. Keller (1993, p.3), says the brand image is a brand perception that is reflected by brand associations that exist in consumers' memories.

Brand image influences consumer purchasing decisions and is one of the main factors considered. Brand image is an extrinsic cue for product quality evaluation, and a better brand image results in high perceived quality (Grewal et al., 1998). Therefore, when cues attached to consumers or other attributes of a product cannot help consumers evaluate the quality of a product, brand image is usually used as a basis for evaluation. According to Aaker \& Keller (1990), a good brand image can increase loyalty, trust and even consumer interest in buying products from brands they trust. Therefore, brand image has a direct influence on product sales volume (Park, Jaworski and MacInnis, 1986).

Brand trust is defined as a sense of security that users of a product have, in their interactions with a brand, based on the perception that the brand can be trusted and pays attention to the interests and welfare of consumers (Keller, 1993). Trust in the brand is a behaviour of consumer willingness, in general, to depend on the ability of the brand to describe the function of its product (Chaudhuri \& Holbrook, 2001). Brand trust is something that can be trusted and trusted (Dawar \& Pillutla, 2000). Availability is not very influential, because of the argument that consumers want to depend on the brand (Morgan and Hunt, 1994).

Brand trust also affects consumer buying interest. Where subjective norms are variables and brand trust attitudes. Brand trust variables affect buying interest with the results all showing a positive value and a significance level of less than $5 \%$, namely 0.00 . Consumer trust in brands affects buying interest because consumers have a more wary attitude towards unknown brands. The strong and positive relationship significantly affects the overall brand trust.

The lifestyles of the net created a brand new paradigm in Word Of Mouth verbal exchange and this become the start of the emergence of the period of electronic Word of Mouth (eWOM.). The eWOM phenomenon is taken into consideration as an evolution from conventional interpersonal verbal exchange to a brand new technology of cyberspace. Advances in facts technology, inflicting an increasing number of customers to search for the facts wanted for a product earlier than creating a buy together with thru Blog, Tokopedia, Lazada, Shopee, Facebook (Social Media). EWOM sports can also additionally create poor or high-quality statements made with the aid of using actual, capacity or preceding customers approximately merchandise or businesses wherein this fact is to be had to human beings or establishments through net media, (Henning-Thurau et al. 2004). 
A high-quality emblem picture might be remembered extra frequently with the aid of using customers if spoken positively, alternatively emerge as much less remembered if spoken negatively with the aid of using phrase of mouth, (Herr et al., 1991). In addition, a better emblem picture ends in a notion of better high-satisfactory and a decrease one will result in a perceived decline in high-satisfactory. More high-quality phrase-of-mouth speech additionally ends in better perceptions of high-satisfactory, and could alternatively result in a lower withinside the notion of high-satisfactory, (Herr et al., 1991). EWOM messages are very crucial messages for customers while seeking to get facts approximately the highsatisfactory of a product or service, and might be a crucial reference withinside the decisionmaking process (Chevalier and Mayzlin 2006).

Purchase intention is a kind of psychological force that exists within individuals, which has an impact on actions (Schiffman \& Kanuk 2007). A product is said to have been consumed when the consumer decides to buy it. Purchase decisions are influenced by the value of the product being assessed. If the perceived benefit is greater than the sacrifice to obtain it, then the desire to buy it is greater. On the other hand, if the benefits outweigh the costs, buyers usually refuse to buy and generally turn to evaluate other similar products.

Consumer buying interest is an individual activity that is directly involved in obtaining and using goods and services, including decision making in the preparation and determination of these activities (Swastha \& Handoko, 2000). This means that consumer buying interest is the actions and social relationships carried out by individual consumers, groups and organizations to assess, obtain, and use goods and services through an exchange or purchase process that begins with a decision-making process that determines action. According to Kotler (2002:181), customer purchasing decisions come from their experience of learning, choosing, using and even spending a product. Consumer buying interest is the behaviour of consumers who have a desire to buy or choose a product, based on experience in choosing, using and consuming or even wanting a product.

Consumer buying behaviour is often initiated and influenced by many external stimuli, both in the form of marketing stimuli and environmental stimuli. The stimulation is then processed in a person based on his characteristics, before finally making a purchase decision. The personal characteristics of consumers used to process these stimuli are very complex and one of them is the consumer's motivation to buy. Buying interest is the tendency of consumers to buy a brand or take actions related to purchases as measured by the level of possibility of consumers to make a purchase (Assael 2001).

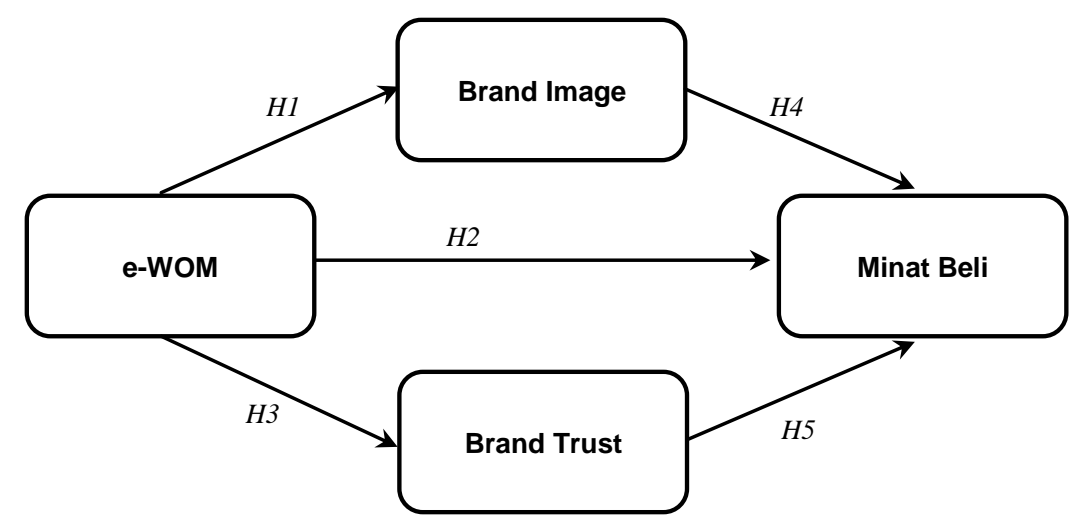

Figure 1 - Research Paradigm

$\mathrm{H} 1$ : There is an influence between e-WOM on Brand Image;

$\mathrm{H} 2$ : There is an influence between e-WOM on Buying Interest;

H3: There is an influence between e-WOM on Brand Trust;

$\mathrm{H} 4$ : There is an influence between Brand Image on Buying Interests;

H5: There is an influence between Brand Trusts on Buying Interests. 


\section{RESULTS AND DISCUSSION}

The population in this study is people in the city of Tangerang who are at least 17 years old and familiar with smartphone products. Samples were taken from 150 respondents using intentional sampling. Data was obtained through a questionnaire on a Likert scale of 1-5 which is widely used as an interval scale. Data were analyzed using Partial Least Square with Smart PLS 3 software application program. The reason for using this analysis tool is due to the suitability of the software with data processing needs. Tests were carried out on various instruments related to the Structural Equation Model to verify the suitability of the model used. Hypothesis testing will be verified indirectly by using the Sobel Test.

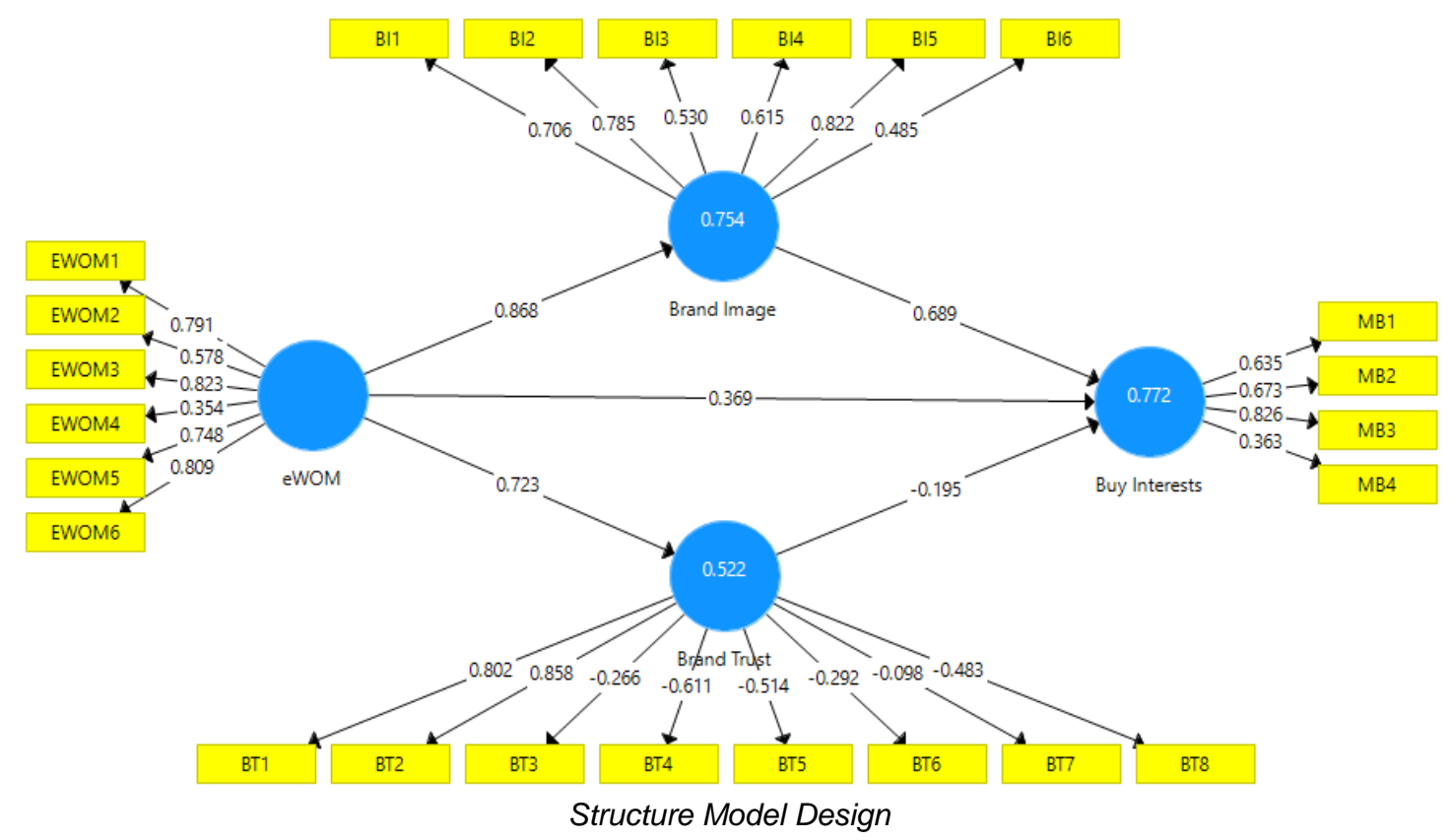

Figure 2 - PLS Algorithm Results

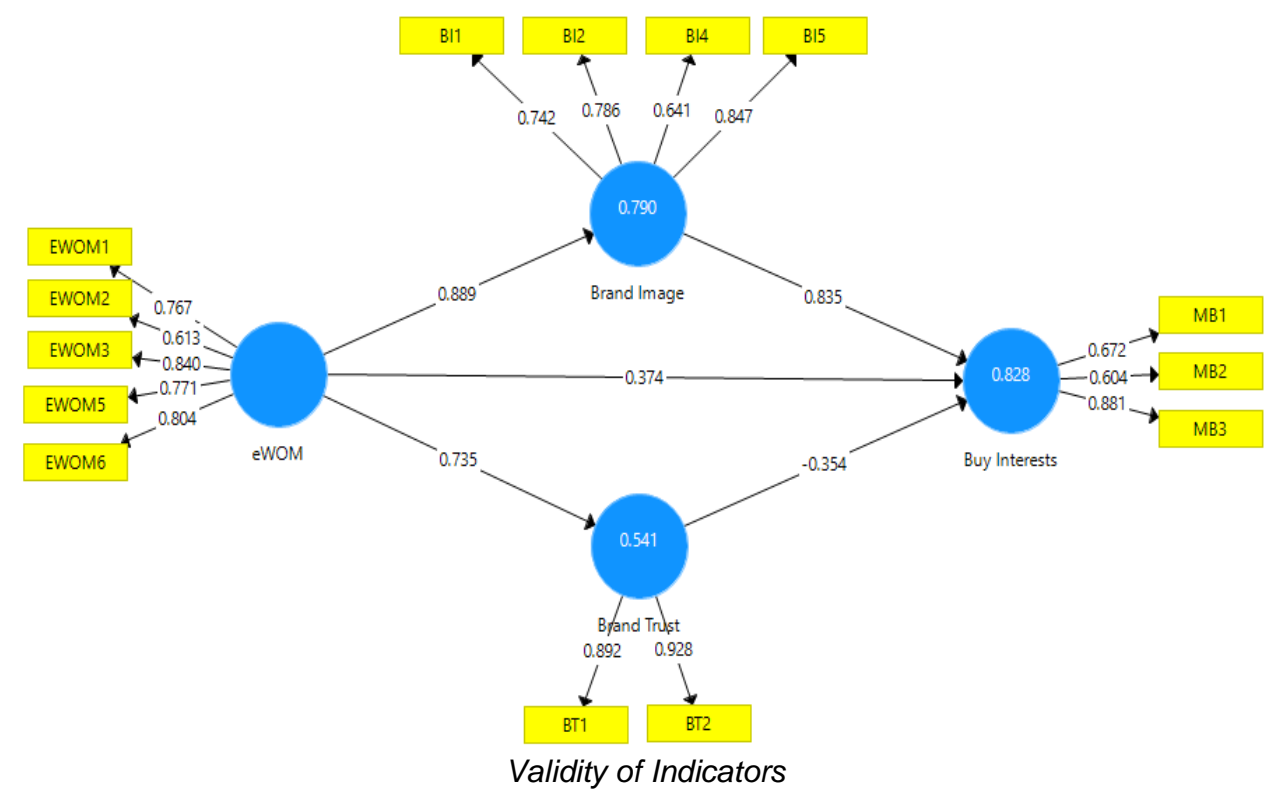

Figure 3 - Indicator Validity Results 
RJOAS, 11(119), November 2021

Table 1 - Reliability Test

\begin{tabular}{|l|l|l|l|}
\hline Construct & Composite reliability & Cronbach's Alpha & Notes \\
\hline eWOM & 0,873 & 0,818 & Reliable \\
\hline Brand Image & 0,842 & 0,749 & Reliable \\
\hline Brand Trust & 0,907 & 0,795 & Reliable \\
\hline Buy Interest & 0,768 & 0,547 & Reliable \\
\hline
\end{tabular}

Source: Smart PLS 3.0 data processing.

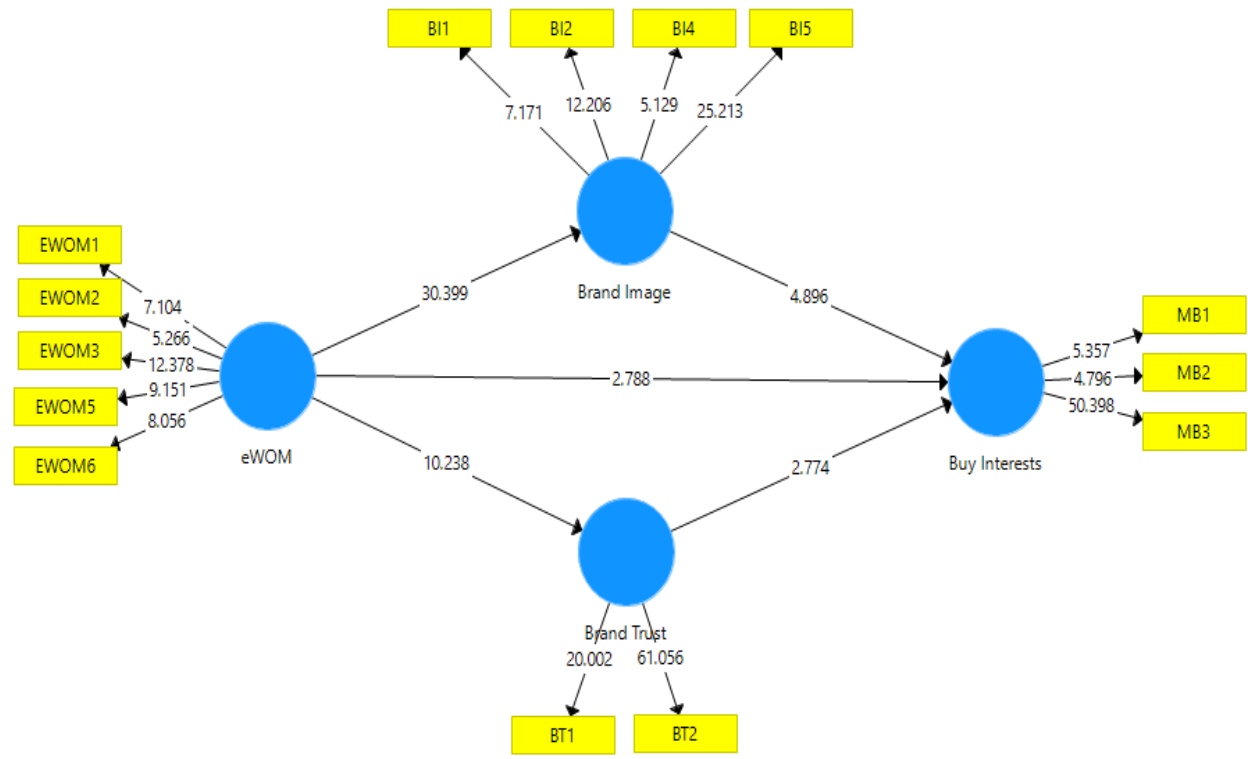

Evaluation Structural Model (Inner model)

Figure 4 - Bootstrapping results

Table 2 - Results of Research

\begin{tabular}{|c|c|c|c|c|c|c|c|}
\hline \multirow{2}{*}{ Hypothesis } & \multicolumn{2}{|l|}{ Variables } & \multirow{2}{*}{$\begin{array}{l}\text { Direct } \\
\text { Effect }\end{array}$} & \multirow{2}{*}{$\begin{array}{l}\text { Indirect } \\
\text { Effect }\end{array}$} & \multirow{2}{*}{$\begin{array}{l}\text { Total } \\
\text { Effect }\end{array}$} & \multirow{2}{*}{$\begin{array}{l}t-\text { Values } \\
(>1.96)\end{array}$} & \multirow{2}{*}{ Notes } \\
\hline & Exogenous & Endogenous & & & & & \\
\hline 1 & eWOM & Brand Image & 0,889 & - & 0,889 & 30,399 & Significant \\
\hline 2 & eWOM & Buy Interest & 0,374 & - & 0,374 & 2,788 & Significant \\
\hline 3 & eWOM & Brand Trust & 0,735 & - & 0,735 & 10,238 & Significant \\
\hline 4 & Brand Image & Buy Interest & 0,835 & - & 0,835 & 4,896 & Significant \\
\hline 5 & Brand Trust & Buy Interest & $-0,354$ & - & $-0,354$ & 2,774 & Significant \\
\hline
\end{tabular}

Source: Smart PLS 2.0M3 data processing.
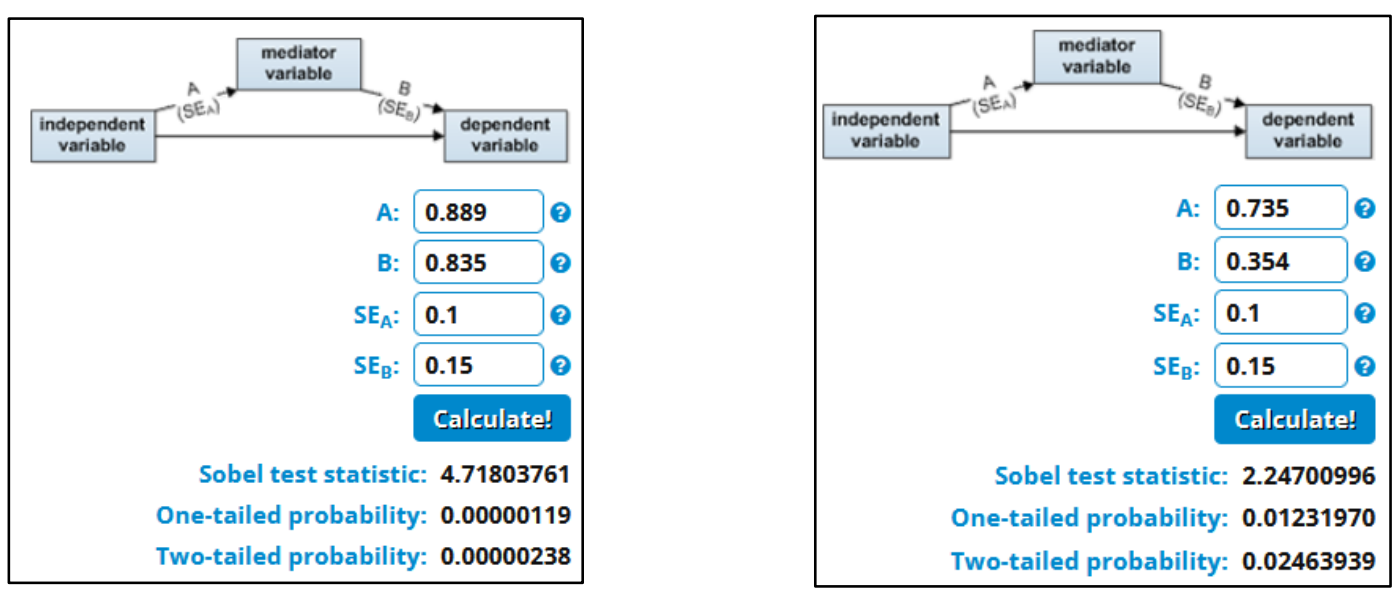

Figure 5 - Sobel Test Results 
From the image above, in this study, the value below the validity standard of 0.5 will be removed. For the eWOM variable, the indicator removed is EWOM4 with an indicator value of 0.358 . As for Brand Image, the indicators removed are BI3 with a value of 0.523 and $\mathrm{BI} 6$ with a value of 0.479 . Followed by Brand Trust, indicators removed BT3 $(-0.283)$, BT4 $(-0.624)$, BT5 $(-0.522)$, BT6 $(-0.312)$, BT7 $(-0.103)$, BT8 $(-0.489)$. Next for variable Buy Interest, with the indicator removed is MB4 with a value of 0.420 .

In this study to look for indirect relationships between variables using the Sobel Test calculations.

From the results of the Sobel test calculation above, it can be concluded that there is a positive and significant influence between eWOM on Buy Interest through Brand Image with a Sobel test statistic of 4,718.

From the results of the Sobel test calculation can be taken a decision there is a positive and significant influence between eWOM to Buy Interest through Brand Trust with a sobel test statistic of 2,247 > 1.96 .

\section{CONCLUSION}

From the results of this study can be concluded that: First, there is a positive and significant influence between eWOM on Brand Image with a value of 30,399 > 1.96 Second, there is a positive and significant influence between eWOM on Buy Interest with a value of $2,788>1.96$. Third, there is a positive and significant influence between eWOM on Brand Trust with a value of $10,238>1.96$. Fourth, there is a positive and significant influence between Brand Image on Buy Interest with a value of 4,896 > 1.96. Fifth, there is a positive and significant influence between Brand Trust on Buy Interest with a value of 2,774 > 1.96. Sixth, there is a positive and significant influence between eWOM on Buy Interest through Brand Image with a Sobel test statistic of 4,718 > 1.96. Seventh, there is a positive and significant influence between eWOM on Buy Interest through Brand Trust with a Sobel test statistic of 2,247 > 1.96 .

\section{REFERENCES}

1. Aaker, D. A., and Keller, K. L. (1990). Consumer Evaluations of Brand Extensions, Journal of Marketing, 54(1), pp. 27-41.

2. Ambler, Tim, and Flora Kokkinaki. (1997). Measures of Marketing Success. Journal of Marketing Management. 13, 665-678.

3. Arndt, J. (1967). Role of product-related conversations in the diffusion of a new product. Journal of Marketing Research. 4, 291-5.

4. Assael, H. (2001). Consumers Behavior and Marketing Action, Edisi 3, Kent Publishing Company, Boston Massachusset, AS.

5. Bone, P. F. (1995). Word-of-Mouth Effects on Shortterm and Long-term Product Judgments. Journal of Business Research. 32(3): 213-223.

6. Buttle, F. A. (1998). Word of mouth: Understanding and managing re-ferral marketing. Journal of Strategic Marketing, 6, 241-254. doi:10.1080/096525498346658.

7. Chaudhuri, A. and Holbrook, M. B. (2001). The chain of effects from brand trust and brand affect to brand performance: the role of brand loyalty. Journal of Marketing, 65, 8194.

8. Chevalier, J., and Mayzlin, D. (2006). The Effect of Word of Mouth on Sales: Online. Book Reviews. Journal of Marketing Research. 43(3), 345- 354.

9. Dawar, N., and Madan, M.P. (2000). Impact of Product Harm Crisis on Brand Equity: The Moderating Role of Consumer Expectations. Journal of Marketing Research. 37(2), 215226.

10. East, R., Hammond, K., \& Lomax, W. (2008). Measuring the impact of positive and negative word of mouth on brand purchase probability. International Journal of Research in Marketing. 25(3), 215-224. 
11. Grewal, K., and Baker, B. (1998). The Effect of Store Name. Brand Name and Price Discounts on Consumers' Evaluations and Purchase Intentions.

12. Hawkins, D.I., \& Mothersbaugh, D.L. (2010). Consumer Behavior: Building Marketing Strategy (11th ed.). New York: McGraw-Hill.

13. Hennig-Thurau., Gwinner, K.P., Walsh, G., and Gremier, D.D. (2004). ElectronicnWordof-Mouth Via Consumer-Opinion Platforms: What Motives Consumers to Articulate Themselves On the Intenet. Journal of Interactive Marketing. 18(1). Winter 2004.

14. Herr, P.M., Kardes, F.R., and Kim, L. (1991). Effects of word-of-mouth and productattribute information on persuasion: An accessibility diagnosti-city perspective. Journal of Consumer Research. 17(4), 454-462.

15. Jalilvand, M.R. (2012). The Effect of Electronic Word-of-Mouth on Brand Image and Purchase Intention. Journals of Marketing Inteligence and Planning. 30(4), 5-5.

16. James E. Haefner, Zsuzsa Deli-Gray and Al Rosenbloom. (2011). Managing Global Transitions. 9(3), pp. 249-273.

17. Jansen, B.J., Zhang, M., Sobel, K., and Chowdury, A. (2009). Twitter Power: Tweets as Electronic Word of Mouth. Journal of the American Society for Information Science and Technology, 60(11), 2169-2188.

18. Keller, K.L. (1993). Conceptualizing, Measuring, and Managing Customer-Based Brand Equity. Journal of Marketing. 57, 1-22.

19. Kotler, P. dan Keller, K.L. (2007). Manajemen Pemasaran. Ed. 12. Jilid 2. Penerbit PT Indeks: Jakarta.

20. Kotler, P. (2002). Manajemen Pemasaran. Edisi, Millienium, Jakarta: Penerbit PT. Prenhallindo.

21. Lau, G.T., and Lee, S.H. (2000). Consumer Trust in Brand and The Link to Brand Loyalty. Journal of Market Focused Management. 4, pp. 341-370.

22. Monroe, K., Suri, R. 2003. The Effects of Time Constraints on Consumer's Judgments of Prices and Products. Journal of Consumer Research, 30, 92-104.

23. Morgan, R.M., and Shelby, D.H. (1994, July) The Commitment-Trust Theory of Relationship Marketing. Journal of Marketing. 58, pp. 20-38.

24. Park, C.W., Jaworski, B.J., and Maclnnis, D. J. (1986) Strategic brand concept-image management. Journal of Marketing. 50(4) October, pp.135-145.

25. Schiffman, L. G. and Kanuk, L. L. (2007). Consumer behaviour. Singapore: Prentice Hall International.

26. Swasta dan Handoko. (2000). Manajemen Pemasaran, Analisis Perilaku Konsumen, Edisi 1, Cetakan 3. Yogyakarta.

27. Vazquez, R., Del Rio, A.B., \& Iglesias, V. (2002). Consumer-based brand equity: Development and validation of a measurement instrument. Journal of Marketing Management, 18(1/2), pp. 27-48.

28. Yoo, B. and Donthu, N. (2001). Developing and Validating a Multidimensional Consumer Based Brand Equity Scale. Journal of Business Research. 52(1), pp. 1-14. 